\title{
BOUNDARIES AND DESIRE: CENSORSHIP AND THE ARTICULATION OF ROMANTIC ENCOUNTERS IN THE WORKS OF RADCLYFFE HALL
}

\author{
Alina Preda \\ Babeş-Bolyai University (Romania)
}

\section{Abstract}

Radclyffe Hall suscitated vigorous antagonistic reactions among her contemporaries, readers and critics alike, through her rendering of same-sex romantic encounters, which often provoked heated disputes on the literary stage and in society at large, ultimately leading to obscenity charges materialised in the banning of the books under investigation. This article focuses on the articulation of love and desire between women in the works that this author wrote and/or published in the 1920s, pointing to the narrative manifestation of self-censorship, as well as to the workings of external censorship and to the effects of these personally inflicted and socially imposed boundaries.

KEYwORDs: Radclyffe Hall, censorship, homosociality, sexuality, desire, feminism, fiction.

\author{
LIMITACIONES Y DESEO: LA CENSURA \\ Y LA ARTICULACIÓN DE LOS ENCUENTROS ROMÁNTICOS \\ EN LAS OBRAS DE RADCLYFFE HALL
}

\section{RESUMEN}

Radclyffe Hall suscitó fuertes reacciones contrapuestas entre sus contemporáneos, tanto lectores como críticos, por su representación de encuentros románticos entre personas del mismo sexo, que a menudo provocaron ardientes disputas en el panorama literario y en la sociedad en general, que condujeron en último término a acusaciones de obscenidad y a la prohibición de sus libros. Este artículo analiza la articulación del amor y el deseo entre mujeres en las obras de esta autora escritas y/o publicadas en los años veinte, y se centra en las manifestaciones narrativas de la autocensura, así como en los procedimientos de censura externa, y en las consecuencias de estas limitaciones infringidas tanto por ella misma como por la sociedad.

Palabras Clave: Radclyffe Hall, censura, homosocialidad, sexualidad, deseo, feminismo, ficción. 


\section{INTRODUCTION}

Of the books banned in the United Kingdom for violation of obscenity laws, many date from the 1920s and were put on trial under the first Obscene Publications Act, which had come into force in 1857 with the eventual aim of safeguarding the underage children, the weaker sex and the feeble-minded against published material considered highly likely to shock or corrupt them. Once the Obscene Publications Act was updated, in 1959, conviction was not infrequently overturned on appeal, as the now-permitted defence of literary merit proved impervious to baseless accusations, specious arguments and fallacious testimony. That, of course, decreased the likelihood of bans being placed on works which previously would have been deemed indecent, such as The Well of Loneliness (1928), charged with obscenity almost immediately after making its appearance on the market. This article focuses on Radclyffe Hall's fictional rendition of same-sex romantic encounters in her prose written and/or published during the1920s, in order to examine the narrative manifestation of selfcensorship together with the effects of external censorship on the author's life and work, as well as on the readership and on the course of literary history.

\section{THE FRAMING OF MORAL PANIC}

One of the most significant developments which jolted the shaping of post-Victorian British literary and social history was Chancellor John Campbell's campaign against what he regarded as indecent publications. On May 9, 1857, the day he first tried an obscenity case, Lord Chief Justice Campbell decided to orchestrate a lobby to have his Obscene Publications Bill passed into law. Throughout the process, which in his imagination assumed the status of a moral crusade, Lord Campbell managed to garner support from fathers young and old, medical men and clergymen, newspapers and periodicals. Thus, the debate was "taken up, extended and amplified by the rapidly expanding London press to the point where it provides an embryo version of what sociologists have since come to describe as a 'moral panic'" (Roberts 1985, 611-612). ${ }^{1}$

The inquisition-minded Lord Campbell succeeded in provoking an exaggerated outburst of public concern due to various factors. On the one hand, it was generally believed that the openness about sex drives characteristic of bawdy literature would enhance "the potential animality of the working classes" (Roberts

1 The notion of moral panic was first developed in the United Kingdom in the early 1970s. Sociologist Stanley Cohen (1942-2013) coined the phrase in his 1972 book Folk Devils and Moral Panics. A moral panic is an often irrational fear that something or someone constitutes a threat to society's safety, values and interests. Such threats are the "folk devils" which, if formulated in a stereotypical way by members of the community and/or by mass-media, may aggrieve the greater public, so the resulting widespread concern will allow politicians to fuel the debate and ultimately pass new policies or laws that trigger social change (see Crossman 2020). 
$1985,612)$; on the other hand, it was feared that respectable middle-class and lowermiddle-class youth lacked the strength to resist temptation and their "pure minds" and "happy hearts" would be subject to "pollution" and "desecration" (614). Thus, it was hoped that the domestication of sexual instincts would preserve not only the physical and the spiritual health of families, but also the moral and social stability of society at large. Apart from these class-related concerns, there was the perplexing lack of response on the part of English writers, especially since in 1856 Gustave Flaubert's Madame Bovary had also been put on trial for obscenity. Apparently, English writers considered themselves much more morally responsible and their reaction was one of self-praise rather than apprehension (618). Consequently, with the support of Church Evangelicals and of the informal Palmerstonian coalition, determined to thwart "systematic institutional reform", the bill passed without much opposition (618). It also benefitted from the change in mentality generated by the Indian Mutiny (May 10, 1857-July 8, 1859), as the general public grew even less inclined towards the acceptance of overtly expressed sentimentality or sexuality, and the progressive elites became "more receptive to a paternalist-imperial set of social priorities at home as well as abroad" (626).

Following the death of Queen Victoria at the turn of the century, mentalities started to change in the aftermath of the First World War and of the $1918 \mathrm{flu}$ pandemic. The huge debt incurred by Britain during the war and the doubling of inflation between 1914 and 1920 led to soaring rates of unemployment, shrinking consumer expenditure to the point of economic collapse, and gave rise to more frequent social unrest and greater assertiveness of Commonwealth nations, whose diplomatic autonomy grew steadily in the 1920s. The subsequent "sullen discontent against all manifestations of authority" (Radu 2001, 52), coupled with an unquenchable lust for life, shaped a new literary trend that broke sundry taboos and overstepped many boundaries, as writers -influenced by the works of notable philosophers, psychiatrists, sexologists and psychoanalysts, such as William James and Søren Kirkegaard, Richard Freiherr von Krafft-Ebing, Havelock Ellis, Sigmund Freud and Carl Gustav Jung- explored a medley of desires, focusing increasingly on issues related to sexual and romantic identity, thus providing more intricate depictions of love encounters.

The social climate drastically transformed with the advent of modernity, an era that valued reason far more than tradition, and was, therefore, characterised by "the presumption of wholesale reflexivity" (Giddens 1990, 39) which seemed "to offer a sense of certitude greater than that provided by pre-existing dogma" (39). Marie Charlotte Carmichael Stopes, founder of Britain's first instructional clinic for contraception, author of Married Love (1918) -which sold in hundreds of thousands of copies and Contraception: Its Theory, History and Practice (1923), played a significant role in "bringing individuals into the age of pleasure and health, mutuality and spiritual union" (Sigel 2012, 165).

Nevertheless, in the aftermath of the Great War, which had drastically disrupted the traditionally sanctioned gender and class relations, the need to reinstate what had been known as "normality" was deeply felt. The cultural renewal of the nation represented an essential part of this process, and it was to be carried out with 
and through "virility" -a term that had become the leitmotif in debates about the state of the nation. Consequently, a more significant meaning and a much higher power were bestowed upon the English novel, which thus became the focus of intensified censorship with the aim of ensuring that "forbidden subjectivities and sexualities" (Sidhe 2001, 3) would not find their way to the reading public. On the one hand, the nation, consistently described as a comradeship or a fraternity, found itself "compelled to distinguish its 'proper' homosociality from more explicitly sexualized male-male relations, a compulsion that requires the identification, isolation, and containment of male homosexuality" (Parker et al. 1992, 6). On the other hand, the national territory was typically depicted as a female body and the vigour of this representation depended on "a particular image of woman as chaste, dutiful, daughterly or maternal" (6). Moreover, the fact that motherhood was idealised by "the virile fraternity" automatically lead to a natural "exclusion of all non-reproductively-oriented sexualities from the discourse of the nation" (7).

Thus, although it was expected that the Obscene Publications Act would be applied less and less frequently after the undesirable shops on Holywell Street had been closed down, it turned out that the above mentioned Act had a long-term impact, despite its rather unsystematic implementation. It comes as no surprise, therefore, that inter-war Britain saw spectacular obscenity trials and blatant censorship attempts bound to have a considerable impact on literary history, such as those involving Radclyffe Hall's The Well of Loneliness.

\section{THE UNWONTED, THE UNUSUAL AND THE UNCANNY}

Born on August 12, 1880 in Bournemouth, Hampshire, England, Marguerite Radclyffe Hall started writing poems in early childhood and her poetry, just like her prose, is permeated by autobiographical particulars: tomboyish behaviour, an interest in psychology, feminist principles, a struggle to make society accept otherness, passionate love of women, a pervasive sense of guilt that often leads to self-sacrifice are just some such aspects featured in Hall's writing. The last of her five volumes of poetry, for instance, The Forgotten Island (1915), contains erotic poems which provide no clarification as to the beloved's gender, thus allowing an informed audience to read between the lines "somewhat veiled references to Radclyffe Hall's 1913-1914 brief love-affair with Phoebe Hoare" (Preda 2012, 449). It was only later that Hall managed to complete her works in prose but, in the year 1924, The Unlit Lamp, a bildungsroman, was published. The main character, Joan Ogden, is a tomboy who dreams of becoming a doctor, even though her mother, Mrs Mary Ogden, berates the child for craving "an altogether ridiculous masculine role" (1924, Book 2, Chapter 18), while her father, Colonel James Ogden, insists that medicine is "[a]n unsexing, indecent profession for any woman" and utterly discourages her: "I'll have none of these new-fangled women's rights in my house; you will marry; do you hear me? That's a woman's profession!" (Book 2, Chapter 18). The young girl initially opposes her parents' patriarchal mind-set and constantly attempts to resist their passive-aggressive manipulative tendencies but, despite the support of her 
tutor, friend and would-be lover, Elizabeth Rodney, she can neither break free from the heavy chains of self-imposed guilt and responsibility, nor defy the implacable societal expectations imposed on women at that time. She remains captive in the south-coast seaside town of Seabourne, whose description strongly reminds readers of Radclyffe Hall's hometown.

One merit of the novel, which dwells on love between women quite extensively, though not very explicitly, is that it describes the relationship between Joan and Elizabeth neither from the congenital inversion perspective, nor in exclusively Freudian terms, but rather as a matter of choice, in line with the political determination characteristic of radical lesbians, who look for a reliable, fair, tender and supportive life-long partner likely to profess, as Elizabeth does to Joan: "I not only want your devotion ... I want your work, your independence, your success" (Book 3, Chapter 20). Yet, although the two women share strong feminist convictions which are, naturally, at odds with the prevailing patriarchal mentality of Joan's parents and of society at large, by the end of the novel Joan has become a heavy-hearted middleaged woman much too old to benefit from the upcoming social change, yet aware of her failure, regretful over her fearfulness, and mindful of the on-going struggle that her younger contemporaries are engaged in: "But she, Joan Ogden, was the forerunner who had failed, the pioneer who feared his own prophecies. These others had gone forward, ... and if the world was not quite ready for them yet, if they had to meet criticism and ridicule and opposition, if they were not all as happy as they might be, still, they were at least brave, whereas she had been a coward, conquered by circumstances" (Book 5, Chapter 44).

Another merit of this pioneering work is that it attributes Joan's unhappiness to her having been born in the wrong era rather than in the wrong body: "without a support group she lacked the courage of her feminist convictions" (Faderman $1985,319)$, and this prevented her not only from pursuing the desired educational path, but also from giving love a fighting chance: "she had not the courage to say straight out that she intended leaving her mother's home for that of another woman ... It was unusual, and because it was unusual she had been embarrassed; a hitherto unsuspected respect for convention had assailed her" (Hall 1924, Book4 Chapter 38).

As its motto suggests ${ }^{2}$, this novel was inspired by The Statue and the Bust, a poem where Robert Browning outlines the love story between "two similarly frustrated heterosexual lovers" (Faderman 1985, 318) and points to "the sin of lukewarmness of will" (Organ 1943, 16) by arguing that all actions, even immoral ones, "should be done wholeheartedly" (16). Indeed, Joan is unable to fully embrace her love for Elizabeth Rodney and to take advantage of the career opportunities that their moving together to London would have opened; she chooses, instead, to sacrifice herself on the altar of daughterly love and to stay behind with her psychologically abusive and emotionally dependant mother.

\footnotetext{
2 "And the sin I impute to each frustrate ghost/Is - the unlit lamp and the ungirt loin" (Robert Browning-The Statue and the Bust).
} 
An equally grim sacrifice marks the ending of Radclyffe Hall's 1928 novel, The Well of Loneliness, as Stephen Gordon, the novel's heroine, pushes her lover, Mary Llewellyn, into the arms of Martin Hallam, despite the passionate love, mutual attraction, and deep affection they still have for one another. Just like the novel's author, the main character is a guilt-ridden fervent Catholic on a mission to reveal the great suffering of homosexuals to the world, in the hope of gaining acceptance or, at least, tolerance for these unfortunate men and women. Since homosexuals are born this way, as part of God's plan, to persecute, torment and destroy them would mean to go against God's wishes. This is the deep conviction of both author and character, yet so is the assumption that life's hardships are much easier to bear when one is part of a relationship favoured, encouraged, and valued by society. Consequently, Stephen decides to let go of the woman she loves by pretending to be in love with another, knowing that in offering Mary "the gift of Martin" (Hall 1992, 439) she was also granting her the chance of having "children, a home that the world would respect, ties of affection that the world would hold sacred, the blessed security and the peace of being released from the world's persecution" (438).

Having been given a masculine name because Lady Anna and Sir Philip, her parents, wanted a son, Stephen was a tomboy keen on reading, riding and hunting. Once a teenager, the girl discovers her love of women and, whereas Sir Philip accepts Stephen's difference and tries to protect her, Lady Anna never does, hoping that her daughter would marry Martin Hallam. Yet he is Stephen's dear friend, and neither romantic love for a member of the opposite sex, nor sexual attraction for a man has any place in the young woman's heart. Thus, his proposal is met with "a kind of dumb horror" (96), "an expression of the deepest repulsion" (97), and "a look as of outrage" (97), which drive the suitor away. After seventeen years of estrangement, Martin re-enters Stephen's life as "an embodiment of heterosexuality" (O'Rourke 1989, 78) that "threatens and undermines what Stephen and Mary have" (78). Martin's successful conquest-attempts prove that The Unlit Lamp can be said to have anticipated the denouement of The Well of Loneliness and this reveals how Hall's self-censorship prevents her from articulating the possibility that two women in love can live together happily ever after. Moreover, although the novel portrays a love that can and does exist between women, it fails to accurately represent the essence of same-sex attraction due to its author's reliance on Krafft-Ebing's and Havelock Ellis's theses regarding 'congenital inversion' and 'sexual inversion'. Thus, as Heather Love pertinently points out, "Stephen's embrace of the medical discourse of inversion offers a textbook example of Michel Foucault's concept of 'reverse discourse', which he describes as the process by which a marginalized group begins to speak on its own behalf in the same terms by which it has been rendered marginal" (2000, 119-120)

Regrettably, Radclyffe Hall, who had announced herself through The Unlit Lamp as one of the foremothers of contemporary lesbian feminism by acknowledging the interrelation between female same-sex love and feminism and by revealing that "women often determine not to marry, that their affections go to other women -not because they are men trapped in women's bodies but because they reject prescribed roles" (Faderman 1985, 319), ultimately abandoned the feminist angle in her later 
works. Consequently, both The Well of Loneliness and her story Miss Ogilvy Finds Herself, published only in 1934, despite having been written as early as 1926, are patterned according to heterosexual social constructs and stereotypes, claiming that homosexuality is a congenital 'defect': "And there are so many of us -thousands of miserable, unwanted people ... hideously maimed and ugly- God's cruel; he let us get flawed in the making" (Hall 1992, 207). Miss Ogilvy Finds Herself does feature some remains of a feminist perspective in its criticism of society's exploitation of the more masculine women's potential during wartime followed by their persecution once peace sets in. Thus, although Miss Ogilvy ends up dead, this short story does not merely constitute a gaunt portrayal of a failed invert or "a bleak assessment of lesbian possibility" (Glasgow), but rather amounts to a critical examination of "a failed culture, one that can accommodate its inverts only in times of national crisis without ever acknowledging their deepest, most primitive, and most natural sources" (Glasgow 2002, n.p.).

According to Maroula Joannou, Hall created female characters whose yearning to build a life together was considered "utopian and unrealisable" (2019, 213). This was the result of "the near absence of any literary tradition in which women were able to express same-sex desire clearly" (213). But a much more influential factor was the self-censorship grounded in an internalised homophobia that seeped through both the author's life and her work. Socialised into believing that heterosexuality is the norm and the normal human condition, Radclyffe Hall, like many other non-heterosexuals for that matter, adopted society's negative views of homosexuality and experienced feelings of self-disgust and even self-hatred. The resulting internalised oppression prevented the writer from endowing her rather masculine female characters with a stronger sense of personal worth and with a more positive outlook on the future of their lesbian relationships. Instead, they are made to sacrifice themselves and their happiness, letting go of their beloved (more feminine) sweethearts who, not being genuine congenital inverts, must be spurred to follow their "own true (heterosexual) nature" (Glasgow 2002, n.p.).

Called "John" by her lovers and friends as early as 1908 , the writer was very keen to drop her feminine first name in a bid for liberation when she entered the literary stage: "Had I remained Marguerite Radclyffe-Hall, I am sure I should now never have written a word" (qtd. in Cline 1997, 18). It is, therefore, not startling that Wilhelmina -the main character in Miss Ogilvy Finds Herself- insisted her real name was William, and that in the novel The Well of Loneliness the child of Lady Anna and Sir Philip Gordon is called Stephen. Both have tomboyish tendencies, masculine appearances, character features deemed manly and a desire to pursue traditionally male leisure activities and to embrace careers that men are normally encouraged to favour. Hall clearly fashioned these central characters according to her own making but, lacking access to other lesbian relationships, she failed to grasp the multifarious nature of lesbianism and, in telling her own story through fiction, put forward infelicitous generalisations that eventually undermined her struggle to open people's eyes to the humanity of homosexuals, who naturally include all those endowed with affection and attraction for people of the same sex, whether masculine or feminine in appearance and personality. 
With self-appointed scientific authorities such as Krafft-Ebing, Havelock Ellis and Sigmund Freud, with no acquaintance of some literary tradition to draw inspiration from and given the subjectivity inherent to a perspective that had been warped by confusion, fear and guilt, it is not surprising that Rafclyffe Hall became a prisoner of her own perceptions, unable to accurately portray the ramifications of homosociality, the depth of same-sex emotional connections and the particularities of homosexual desire. Moreover, the "social-corporeal economy" (Hope 1998, 143) of the 1920s regarded same-sex love "as the freakish trauma of difference, as perversion and aberration" (143) and saw in any same-sex relationship the masculine woman as corrupt and the feminine one as her prey, respectively the feminine man tainted and the masculine one his victim. This profoundly influenced Radclyffe Hall's attempt to break the taboos and write, against the grain, her impassioned plea for forgiveness, understanding and recognition of homosexuals' existence and participation in society.

\section{THE TRIALS OF RADCLYFFE HALL}

Radclyffe Hall's intention was to counter society's negative perceptions of sexual otherness, as well as the resulting intolerance and stigmatisation, through works that begged compassion, leniency and acceptance for all homosexual individuals. While her works coalesced around this noble goal, the political climate of the age and the position that homosexuality occupied in the cultural imagination of that time orchestrated Hall's demise. The Well of Loneliness was subjected to a trial that lasted from November 9 to December 14, 1928. The novel was condemned as an obscene libel and all its copies were ordered to be seized and destroyed by burning in the King's furnace. Many publicly acclaimed personalities believed that the novel should not have been withdrawn, but either refused to appear as witnesses in court, or were not given the opportunity by the prosecution: E.M. Forster, John Galsworthy, George Bernard Shaw, Vita Sackville-West, as well as Leonard and Virginia Woolf. As early as October 4, in fact, Dover customs officials had impounded the copies of the book meant to reach the United States and, even when they should have been released, once the two-week legal custody had expired, the Metropolitan Police re-seized them using Lord Campbell's Obscene Publications Act of 1857. On December 15, however, the novel finally penetrated the American market, where over 20,000 copies were sold in less than a month. But on January 22, 1929 charges were brought against its publishers for the violation of Section 1141 of the Penal Code, pertaining to the circulation of indecent literature. Prominent figures of the day, ready to lend their support to the defence team, among whom there were Sherwood Anderson, Theodore Dreiser, John Dos Passos, Edna Ferber, Ernest Hemingway, Harry Sinclair Lewis, Upton Sinclair, American neurologist Dr Joseph Collins and Prof. Boris Sokoloff, Russian politician and cancer researcher, significantly contributed to the court's decision that "[t]he book in question deals with a delicate social problem which, in itself, cannot be said to be in violation of the law unless it is written in such a manner as to make it obscene" (Brittain 1968, 148). One of the defence lawyers, 
Morris Ernst, invoked America's constitutional right to freedom of expression, as he rhetorically asked: "who should or could determine the dangerous consequences of one subject rather than another? Would the 'unorthodox emotional complications' of The Well of Loneliness cause more havoc than sadism in Uncle Tom's Cabin, abortion in The American Tragedy, the adulteries in contemporary fiction, or the murders, robberies and violence in crime novels?" (Souhami 1999, xVIII). Thus came about the vindication of an author who had been compelled to sell her home in the aftermath of the British trial, and who, now, saw an American "victory edition" (xviII) of her novel published. Hall received royalty payments in the amount of $\$ 64,000$. Despite the American triumph, however, it was only in 1949, six years after Radclyffe Hall's death, that the British ban on the book got lifted.

The crucial victory secured in the United States and the "forbidden fruit" label attached to her novel turned The Well of Loneliness into an unusually controversial book for feminists and lesbians. Whereas Del Martin and Jane Rule considered it the "Lesbian Bible" (qtd. in Faderman 1985, 322), Romaine Brooks saw it as "a ridiculous book, trite, superficial" (qtd. in Gilbert and Roche 1987, 178), Violet Trefusis viewed it as "a loathsome example" (qtd. in Gilbert and Roche 1987, 178) and Vita Sackville-West as living proof that "a really good novel remains to be written on that subject" (qtd. in Gilbert and Roche 1987, 178). Virginia Woolf regarded it as so dull that "any indecency may lurk there -one simply can't keep one's eyes on the page" (qtd. in Souhami 1999, ii) and, consequently, Diana Souhami argued, this novel would simply have "passed into oblivion as an unremarkable piece of period fiction" (1999, ii) if only the main character had been a man. Instead, due to the obscenity trials, from 1928 to the 1970s at least, there cannot have been any lesbian "capable of reading in English or any of the eleven languages into which the book was translated who was unfamiliar with The Well of Loneliness" (Faderman 1985, 322).

According to some feminist scholars, the genuine Radclyffe Hall famouslesbian-novel should have been The Unlit Lamp, even though it depicts the love between Joan and Elizabeth "elliptically, through metaphor and allusion" (Joannou 2019, 213). Muted as their love may be, since lesbianism is "never narratively realised" (Hope 1998, 126) in the 1924 novel, the articulation of desire is here untainted by congenital inversion theories, which allows even contemporary readers to empathise with the characters. Still, as Trevor Hope points out, although there are important dissimilarities in what regards these two works' representation of "community, politics, female homosociality and homosexuality" $(1998,125)$, there are also persistent ambivalences "across the two works" (125) inherent in the manner in which "lesbian sexuality and the lesbian body address themselves to the social gaze -and articulate themselves within and against the social body- of a modernity marked by the asymmetric economy of sexual difference" (125). Among the "cruces and crises" (124) revealed by the criticism of Hall's works, Hope mentions those

between feminism and lesbianism, between romantic friendship and lesbian pathology, homosocial continuity and the dialectics of desire; between womanidentification and gender transgression, gender normativity and congenital 
inversion; between sociological and medical, or psychical and somatic readings of lesbianism; between social constructionist and biologically essentialist forms of critical and political practice; between optimism and pessimism, health and disease, inclusion and outlawry, sociality and criminality; between The Unlit Lamp and The Well of Loneliness. $(1998,124)$

Oblivious as she may have been to the considerable variety of lesbian experiences, Radclyffe Hall was a rebel with a cause, and -as her lover, Una Troubridge, explained- "it was her absolute conviction that such a book could only be written by a sexual invert, who alone could be qualified by personal knowledge and experience to speak on behalf of a misunderstood and misjudged minority" (qtd. in Nair 2012, 36). Consequently, Hall was furious with her lawyer, who had structured the defence of the novel in such a way as to persuade the court that it merely portrayed simple friendships between women. Even when under the intrusive and unwelcome gaze of the law, the author refused to deny that one of the aspects she had been interested in exploring was the kind of physical intimacy which does not live outside romantic spaces, and that an element of sensuality plays into the ways in which Stephen interacts with female characters such as Collins, Angela Crossby and Mary Llewellyn. Hall, thus, refused to be disciplinarily bound "within the suffocating proximity of a hygienically censored rendition of homosociality" (Hope 1998, 144). As a result, despite the fact that it includes neither strands of blue language, nor steamy fragments, with the arguable exception of sentences like "she kissed her full on the lips, as a lover" (Hall 1992, 144) and "that night they were not divided" (316), The Well of Loneliness was condemned as an obscene libel to be burnt in the King's furnace.

Ellen Bayuk Rosenman argues that this conviction on the basis of the Obscene Publications Act had a particularly strong impact in English literary circles: "That a writer of Hall's stature should be so vulnerable was shocking, for she was one of only two writers to receive both the Prix Femina and the James Tait Black prize, two of the most prestigious literary awards in England. ${ }^{3}$ Society might be ready to read and reward women writers, but lesbianism remained literally unspeakable" (1989, 639). Virginia Woolf, for instance, whose widely acclaimed Orlando, also published in 1928, had escaped censorship due to the fact that the lesbian allusions contained within were "too aerial and fantastic to invite scrutiny by the Home Secretary" (Souhami 1999, xIx), had intended to include in A Room of One's Own's fifth chapter a vision of the narrator that contained explicit references to Chloe and Olivia's romantic and erotic partnership. It was the end result of Radclyffe Hall's trial that determined Woolf to cut from her draft this vision, which would have evoked in the narrator's mind "vivid images of a summons, an obscenity trial, a book burning” (Rusk 2002, 25). Lauren Rusk explains that Woolf's reluctance to

${ }^{3}$ Radclyffe Hall's critically acclaimed novel, Adam's Breed, published in 1926, had been awarded not only the Prix Femina, but also the James Tait Black Prize, which was no mean feat, as both these prizes had previously been won only by E.M. Forster's A Passage to India. 
mention Hall's trial in A Room of One's Own, although she had previously considered taking a stance against the censoring of lesbian fiction, sprang out of a "need for professional self-preservation" (25). This is but one indication that the outcome of the trial had deep and contiguous ramifications in English literary history.

Another after-effect was that the firm of solicitors hired to defend The Well of Loneliness would represent, twenty years later, Penguin Books Ltd., prosecuted under The Obscene Publications Act of 1959 for publishing an unexpurgated edition of D.H. Lawrence's 1928 novel Lady Chatterley's Lover, only this time "with a very different result" (Brittain 1968, 87). That, of course, was also due to the significant change brought to the Obscene Publications Act at the request of the Society of Authors, founded in 1884, change which permitted that defence be conducted by invoking artistic merit or public good. It was thus demonstrated that, although laws "confirm a primary function of moral panics: the reaffirmation of society's moral boundaries" (Critcher 2017, n.p.), when the perceived threat is "largely mythical" (n.p.), such laws become ritualistic rather than effective.

\section{CONCLUSION}

Living in a society whose institutional forces violently interfered in the personal sphere and writing at a time when heterosexuality was the national norm against which other sexualities were measured, Radclyffe Hall has evidently both triumphed and failed in her attempt to break the taboos in order to lay bare the tragedy of unspeakable wounds inflicted on a sexual minority by relentless agents of social injustice. It would have been impossible for any author at the beginning of the twentieth century to provide an accurate and all-encompassing depiction of homosexuality in general, or even of lesbianism in particular, without erasing any of its complexities. Hall merely produced an essentialised version of a butch lesbian because she had to rely on personal experience and on the limited knowledge available to her once Krafft-Ebing, Ellis, Freud and Jung had pried open the doors to the bedroom. And whilst she did, woefully, endanger the peaceful existence of several manly-looking women who lived either alone or in romantic partnerships with a female friend or lover, she also offered many a woman the chance to, at least, read about a kind of love she had always dreamt of but could never find, and the hope that she one day would.

It is unfortunate, indeed, that, since Hall always wrote under the spectre of both self-censorship and outer censorship, the more or less explicit renditions of female same-sex emotional and physical relationships in her writings are blighted by the darkness of the portrayal. The characters in question are rebellious, yet often maddened and confused, so that they live their lives in quiet desperation, submitting to the will of others. On the one hand, the selflessness of the more masculine female characters gradually becomes a weakness and they embrace a painful martyrdom, whilst deploring their wasted chances. The more feminine heroines, on the other hand, inspired by sheer despair, eventually allow themselves to become victims of convention, unable to break the chains of traditional expectations. 
That The Well of Loneliness was targeted by the architects of moral panic, gratuitous and distressful as this may have been, ultimately gained international fame for the author and brought same-sex desire into the public eye. Hall's writings are trapped in history because their self-limiting scope mirrors the heterosexualising cultural matrix of the Roaring Twenties in Britain and portrays the tragedy of hope in the case of a writer bent on eliciting social justice for those born, like her, under the sign of sexual difference. Hall was not aware that feeding that kind of hope was tantamount to ignoring the sturdiness of a social, cultural, religious and political mentality which would prove to be shockingly obdurate for decades to come. Yet the misrepresentation and thrashing of both the work and the writer throughout much of the lesbian and feminist scholarship is most regrettable and clearly unwarranted. Hall succeeded in making women's romantic and sexual attraction for other women the subject of literary focus in both poetry and prose. She pressured the authorities, as well as the reading public, to acknowledge the fact that other identities than the heterosexual one existed and, against the backdrop of aggressive neglect, provided visibility to a marginalised group whose presence had, until then, largely been erased. Posterity should, therefore, salute and pay tribute to Radclyffe Hall's audacity since, at great personal cost, she engaged in a calculated act of countercultural courage and resistance by employing the scientific and medical discourse of the day in her fictional works. Hall broke the silence surrounding the existence of a sexual minority for whom persecution is, to this very day, not only past but, painfully, present as well.

Reviews sent to the author: 07/11/2021 Revised paper accepted for publication: 20/12/2021 


\section{WORKS CITED}

Brittain, Vera. 1968. Radclyffe Hall. A Case of Obscenity? London: Femina Books Ltd.

Cline, Sally. 1997. Radclyffe Hall: A Woman Called John. London: John Murray.

Critcher, Chas. 2017. “Moral Panics.” Oxford Research Encyclopedias, 29 March. Accessed 20 July 2021. https://oxfordre.com/criminology/view/10.1093/acrefore/9780190264079.001.0001/ acrefore-9780190264079-e-155.

Crossman, Ashley. 2020. “A Sociological Understanding of Moral Panic.” ThoughtCo, December 18. Accessed 20 July 2021. https://www.thoughtco.com/moral-panic-3026420.

Faderman, Lillian. 1985. Surpassing the Love of Men. London: The Women's Press Ltd.

Giddens, Anthony. 1990. The Consequences of Modernity. Cambridge: Polity Press.

Gilbert, Harriett \& Christine Roche. 1987. A Women's History of Sex. London: Pandora Press.

Glasgow, Joanne. 2002. Entry “Hall, Radclyffe (1880-1943).” In Glbtq: An Encyclopaedia of Gay, Lesbian, Bisexual, Transgender, and Queer Culture, edited by Claude J. Summers, n.p. Glbtq, Inc. Accessed 30 May 2011. http://www.glbtq.com/literature/hall_radclyffe.html.

Hall, Radclyffe. 1924. The Unlit Lamp. London: Cassell. Accessed 20 June 2021. http://gutenberg. net.au/ebooks07/0701131h.html.

Hall, Radclyffe. (1928) 1992. The Well of Loneliness. London: Virago Press Limited.

Hope, Trevor. 1998. "Mother, Don't You See I'm Burning? Between Female Homosexuality and Homosociality in Radclyffe Hall's The Unlit Lamp." In Coming out of Feminism? edited by Mandy Merk, Naomi Segal and Elizabeth Wright, 123-152. Oxford: Wiley Blackwell.

Joannou, Maroula. 2019. “The Female Bildungsroman in the Twentieth Century.” In A History of the Bildungsroman, edited by Sarah Graham, 200-216. Cambridge: Cambridge University Press.

Love, Heather. 2000. "Hard Times and Heartaches". Journal of Lesbian Studies 4 no. 2: 115-128.

NaIr, Sashi. 2012. Secrecy and Sapphic Modernism. Reading Romans à Clef between the Wars. London: Palgrave Macmillan.

Organ, Troy. 1943. "Browning's Message for Dark Days." College English 5 no. 1 (Oct.): 13-18.

O'Rourke, Rebecca. 1989. Reflecting on The Well of Loneliness. London: Routledge.

Parker, Andrew, Mary Russo, Doris Sommer \& Patricia Yaeger. 1992. “Introduction.” In Nationalisms and Sexualities, edited by Andrew Parker, Mary Russo, Doris Sommer and Patricia Yaeger, 1-20. London: Routledge.

Preda, Alina. 2012. "Radclyffe Hall's Literary Works at the Interface between the Discourses of Medicine and Law”. Philobiblon XVII no. 2 (July-Dec.): 448-463.

Radu, Adrian. 2001. The Sign of the Phoenix. Cluj-Napoca: Napoca Star.

Roberts, M.J.D. 1985. "Morals, Art, and the Law: The Passing of the Obscene Publications Act, 1857." Victorian Studies 28 no. 4: 609-629.

Rosenman, Ellen Bayuk. 1989. “Sexual Identity and A Room of One's Own: 'Secret Economics' in Virginia Woolf's Feminist Discourse.” Signs: Journal of Women in Culture and Society 14 no. 3: 634-650.

Rusk, Lauren. 2002. The Life Writing of Otherness: Woolf, Baldwin, Kingston and Winterson. London: Routledge. 
Sidhe, Wren. 2001. Bodies, Books and the Bucolic: Englishness, Literature and Sexuality, 1918-1939. PhD Diss. Gloucester: Cheltenham and Gloucester College of Higher Education.

Sigel, Lisa Z. 2012. Making Modern Love: Sexual Narratives and Identities in Interwar Britain. Sexuality Studies series. Philadelphia: Temple University Press.

Sounami, Diana. 1999. The Trials of Radclyffe Hall. New York: Doubleday, Random House Inc. 